\title{
Pengaruh Hedonic Shopping Motivations terhadap Impulsive Buying pada Konsumen Produk Fashion
}

\author{
DIYAH RANASARI \& FAJRIANTHI*
}

Departmen Psikologi Industri dan Organisasi, Fakultas Psikologi Universitas Airlangga

\begin{abstract}
ABSTRAK
Penelitian ini memiliki tujuan untuk mengetahui pengaruh hedonic shopping motivations terhadap impulsive buying pada konsumen produk fashion. Penelitian ini dilakukan kepada 160 responden dengan rentang usia 19 - 25 tahun dan pernah melakukan pembelian produk fashion tidak terencana minimal satu bulan sekali di Shopee. Alat ukur dalam penelitian ini menggunakan Impulsive Buying Tendency (IBT) dan skala Hedonic Shopping Motivations. Kemudian, data dianalisis menggunakan program software IBM SPSS 25.0 for Windows melalui uji regresi linear sederhana. Hasil analisis data menunjukkan adventure shopping memiliki nilai $R^{2}$ sebesar 0,273, value shopping sebesar 0,110, idea shopping sebesar 0,251, social shopping sebesar 0,142, dan relaxation shopping sebesar 0,237. Hal ini menunjukkan bahwa dimensi adventure shopping memiliki pengaruh terhadap impulsive buying sebesar $27,3 \%$, value shopping sebesar $11 \%$, idea shopping sebesar $25,1 \%$, social shopping sebesar $14,2 \%$, dan relaxation shopping sebesar $23,7 \%$.
\end{abstract}

Kata kunci: hedonic shopping motivations, impulsive buying, produk fashion

\begin{abstract}
The research aims to determine the effect of determine the effect of hedonic shopping motivations to impulsive buying on customers who make purchases of fashion products. This research was conducted to 160 respondents with age range of 19-25 years old and have made an unplanned fashion product purchases at least once a month. Data collection techniques in this study are Impulsive Buying Tendency (IBT) and Hedonic Shopping Motivations scale. The data analysis used in this study using a simple linear regression through SPSS 25 for Windows. The data analysis revealed that adventure shopping has a $\mathrm{R}^{2}$ value of 0,273 , value shopping with 0,110 , idea shopping with 0,251 , social shopping with 0,142 , and relaxation shopping with 0,237 . It means that adventure shopping has an effect on impulsive buying by $27,3 \%$, value shopping has an effect on impulsive buying by $11 \%$, idea shopping has an effect on impulsive buying by $25,1 \%$, social shopping has an effect on impulsive buying by $14,2 \%$, and relaxation shopping has an effect on impulsive buying by $23,7 \%$.
\end{abstract}

Keywords: fashion products, impulsive buying, hedonic shopping motivations

Buletin Penelitian Psikologi dan Kesehatan Mental (BRPKM), 2021, Vol. 1(1), 460-469

*Alamat korespondensi: Fakultas Psikologi Universitas Airlangga, Kampus B Universitas Airlangga Jalan Airlangga 4-6 Surabaya 60286. Surel: fajrianthi@psikologi.unair.ac.id

Naskah ini merupakan naskah dengan akses terbuka dibawah ketentuan the Creative Common Attribution License (CC-BY-4.0) (http://creativecommons.org/licenses/by/4.0), 
sehingga penggunaan, distribusi, reproduksi dalam media apapun atas artikel ini tidak dibatasi, selama sumber aslinya disitir dengan baik.

\section{P E N D A H U L U A N}

Perkembangan teknologi dan informasi yang semakin pesat dan canggih memberi banyak perubahan dan pengaruh dalam berbagai aspek kehidupan, salah satunya sektor bisnis. Aktivitas manusia juga menuntut para pelaku bisnis untuk menyediakan layanan produk dan jasa dengan cepat sesuai permintaan konsumen. Maka dari itu, muncul inovasi yang menggunakan media internet sebagai penghubung antara produsen dan konsumen secara efektif dan efisien.Pengguna internet di Indonesia mengalami peningkatan dari tahun ke tahun, pada tahun 2018 mencapai 143 juta penduduk, kemudian pada tahun 2019 jumlah pengguna internet mencapai 150 juta penduduk. Tahun 2020, pengguna internet mengalami kenaikan sebanyak 175,4 juta penduduk (Kemp, 2020). Teknologi internet membantu aktivitas yang dilakukan oleh konsumen dalam kehidupan sehari-hari serta menunjang aktivitas mereka dalam mencari kebutuhan bahkan hingga pemenuhan keinginan. Hal ini memberi peluang bagi para produsen untuk menciptakan pemenuhan kebetuhan serta keinginan bagi konsumen tersebut dengan media e-commerce. E-commerce atau electronic commerce merupakan layanan jual beli produk dan jasa melalui internet (Khan, 2016).

Impulsive Buying dapat dikatakan menjadi salah satu faktor meningkatnya pengguna e-commerce. Penjualan yang terjadi pada e-commerce terdiri dari pembelian terencana dan pembelian tidak terencana yang dilakukan oleh konsumen (Verhagen \& Dolen, 2011). Sebanyak 28,3\% konsumen di Indonesia merupakan konsumen impulsif (Marketeers, 2012). Apabila pembelian impulsif meningkat maka penjualan pada e-commerce akan meningkat juga (Verhagen \& Dolen, 2011).

Dampak negatif dari Impulsive Buying adalah terjadinya pembengkakan pengeluaran, rasa penyesalan yang dikaitkan dengan masalah keuangan, hasrat berbelanja untuk memanjakan diri dan rasa kecewa dengan membeli produk secara berlebihan. Kemudian, terkait harga yang dianggap telah dipotong yang kenyataannya tidak selalu benar. Hal ini merupakan salah satu strategi sebagian pebisnis ritel dengan menaikkan harga sedemikian rupa sebelum diadakan banting harga besar-besaran dengan tujuan untuk memberikan persepsi nilai yang lebih dari suatu produk sehingga harga yang ditawarkan seolah-olah murah (Yaqoub, 2020). Adanya inovasi cicilan melalui kartu kredit, fasilitas "bayar kemudian", direct marketing, dan in-home shopping juga berkontribusi pada mudahnya konsumen untuk melakukan pembelian secara impulsif (Rook, 1987).

Proses keputusan pembelian terjadi ketika konsumen mengenali kebutuhan yang tidak terpuaskan. Pemahaman mengenai jenis keputusan konsumen inilah yang akan digunakan pemasar untuk mengidentifikasikan kebutuhan dari konsumen. Proses pengambilan keputusan konsumen dibagi menjadi tiga, antara lain pemecahan masalah secara luas, pemecahan masalah secarah terbatas, dan proses pengambilan keputusan yang bersifat kebiasaan (Utami \& Sumaryono, 2008).

Menurut Global Web Index, Indonesia memiliki tingkat pengguna e-commerce yang tertinggi, yaitu 90\% dari pengguna internet. Pada tahun 2018, konsumen e-commerce di Indonesia menghabiskan US\$20,3 miliar, jumlah ini meningkat 20\% dari tahun 2017 (Kemp \& Moey, 2019). Hal ini menunjukkan bagaimana masyarakat telah terbuka secara global dan melakukan pembelian secara online. 
E-commerce telah menjadi bagian dari adanya perubahan social budaya dalam masyarakat, konsumen akan mendapatkan pengalaman yang tidak bisa didapatkan bila melakukan transaksi pada toko fisik, seperti berbelanja di $e$-commerce tidak dibatasi oleh jarak, e-commerce juga membantu konsumen menghemat waktu dan biaya perjalanan karena tidak perlu datang ke toko fisik, kemudian e-commerce menyediakan produk yang bervariasi dan informasi lengkap yang mempermudah konsumen mencari produk yang ingin dibeli. Selain itu, konsumen juga dapat membandingkan harga produk antara toko satu dengan toko lainnya. E-commerce juga memiliki banyak penawaran dan diskon, diantaranya konsumen juga dapat melakukan group buying, yaitu menggunakan satu kupon diskon dalam satu kali transaksi untuk membeli produk dari beberapa toko. Yang terpenting, e-commerce tersedia kapanpun karena tidak ada batasan buka dan tutup toko (Khurana, 2019). Sebanyak 46,4\% konsumen memiliki persepsi bahwa harga di e-commerce lebih murah sehingga banyak konsumen memilih untuk belanja di e-commerce (Mahatma, 2016).

Selain menguntungkan bagi konsumen, banyaknya transaksi pembelian ini memberi kontribusi pada pertumbuhan ekonomi negara berupa bertambahnya PDB (Produk Domestik Bruto). Menurut Bank Indonesia, pada tahun 2019 jumlah transaksi dalam e-commerce perbulannya mencapai Rp 11 triliunRp 13 triliun sehingga e-commerce memiliki prospek yang menjanjikan sebagai tulang punggung perekonomian Indonesia (Apriyani, 2020). Begitu juga halnya pada masa pandemi seperti saat ini, pemerintah melirik e-commerce sebagai salah satu solusi untuk mengatasi defisit pajak akibat pelambatan ekonomi.

Beberapa penelitian mengungkapkan bahwa impulsive buying dapat memuaskan beberapa kebutuhan hedonis, yaitu berbelanja untuk mencari kesenangan, kejutan, dan konsumen impulsive buying memperlihatkan perasaan terhibur, senang, dan antusias yang tinggi (Weinberg \& Gottwald, 1982, dalam Ozen \& Engizek, 2014). Lim dan Hong (2004, dalam Ozen \& Engizek, 2014) menyatakan hedonic shopping motivations mendorong konsumen untuk melakukan impulsive buying.

Menurut Ozen dan Engizek (2014), hedonic shopping motivations memberikan pengalaman pada konsumen saat berbelanja, seperti rasa senang saat berbelanja dan mengalami hal-hal baru. Terdapat lima dimensi dari hedonic shopping motivations, yaitu adventure shopping, value shopping, idea shopping, social shopping, dan relaxation shopping (Ozen \& Engizek, 2014).

Kelima aspek hedonic shopping motivations diatas dapat ditemui di e-commerce. Pada halaman depan $e$ commerce konsumen akan dihadapkan dengan rekomendasi produk, pop-up ads, informasi flash sale, hingga informasi penawaran diskon yang sedang berlaku. Selain itu, e-commerce mengklasifikasikan produknya ke kategori-kategori yang nantinya memudahkan konsumen untuk mencari produk yang diinginkan, seperti kategori pakaian, handphone dan aksesoris, perawatan dan kecantikan, perlengkapan ibu dan bayi, sepatu pria dan wanita, hingga perlengkapan rumah. Hal-hal tersebut dapat menarik perhatian konsumen untuk melakukan adventure shopping dan idea shopping yang dapat mendorong konsumen melakukan pembelian impulsif. Selain itu, keramahannya dalam memberikan promosi "gratis ongkir", kupon diskon hingga 90\%, promosi cashback hingga 50\%, hingga flash sale. Banyaknya promosi yang ditawarkan akan mendorong konsumen untuk melakukan value shopping. Selain berbelanja, konsumen juga dapat berinteraksi dengan konsumen lainnya melalui fasilitas "review product" dan dapat dengan bebas membagikan tautan sebuah produk untuk didiskusikan, hal ini merupakan bagian dari social shopping (Bagas, 2020). Kemudian relaxation shopping didorong dengan banyaknya penawaran dan kenyamanan yang ditawarkan sehingga konsumen senang dan puas berbelanja di e-commerce. Diketahui Indoensia memiliki tingkat kepuasan konsumen mencapai 96\% 
dimana jumlah ini meningkat sebesar 2,5\% disaat beberapa negara berkembang lainnya mengalami penurunan (Kurniawan, 2014).

Berdasarkan pemaparan diatas, penelitian ini dilakukan dengan tujuan untuk mengetahui pengaruh hedonic shopping motivations terhadap impulse buying pada konsumen produk fashion.

\section{Impulsive Buying}

Menurut Verplanken dan Herabadi (2001) impulsive buying merupakan pembelian tidak rasional yang diasosiasikan dengan pembelian tidak terencana, cepat, dan diikuti dengan adanya konflik kognitif serta emosional sehingga seringkali dilakukan tanpa adanya pertimbangan manfaat dari pembelian tersebut. Impulsive buying memiliki 2 dimensi, yaitu dimensi kognitif dan dimensi afektif. Dimensi kognitif merupakan kurangnya perencanaan dan pertimbangan individu dalam mengambil keputusan sebelum melakukan pembelian. Sedangkan dimensi afektif lebih menjelaskan respon emosional individu yang mungkin muncul saat sebelum, bersamaan, dengan atau sesudah melakukan pembelian (Verplanken \& Herabadi, 2001).

\section{Hedonic Shopping Motivations}

Arnold dan Reynolds (2003, dalam Ozen dan Engizek, 2014) mendefinisikan hedonic shopping motivations sebagai pengalaman yang dirasakan konsumen saat berbelanja, seperti perasaan girang. Hal ini dikarenakan berbelanja dikenal memiliki fungsi escapist, yaitu berbelaja untuk membantu melupakan permasalahan yang sedang dihadapi dan memberikan waktu untuk bersenang-senang (Arnold \& Reynolds, 2012). Sehingga hedonic shopping motivations dipandang sebagai pengalaman positif yang memuaskan konsumen secara emosional terlepas dari terjadinya proses pembelian (Ozen \& Engizek, 2014). Hedonic shopping motivations memiliki lima dimensi, yaitu adventure shopping, value shopping, idea shopping, social shopping, dan relaxation shopping.

1. Adventure Shopping

Merupakan dimensi dimana konsumen menemukan hal baru yang menarik dan merasakan kesenangan tersendiri saat melakukan pencarian di e-commerce. Konsumen berbelanja untuk menstimulasi mood dan merasakan berada di dunianya sendiri (Ozen \& Engizek, 2014).

\section{Value Shopping}

Dimensi dimana konsumen merasakan kesenangan saat melihat sale, mencari potongan harga, dan berburu harga murah. Konsumen akan merasa dirinya pandai saat mampu mendapatkan barang dengan harga murah (Ozen \& Engizek, 2014).

\section{Idea Shopping}

Dimensi dimana kegiatan berbelanja digunakan untuk mengikuti perkembangan tren terbaru serta untuk melihat produk dan inovasi terbaru (Ozen \& Engizek, 2014).

\section{Social Shopping}

Dimensi dimana konsumen menganggap berbelanja sebagai suatu sarana untuk bersosialisasi dengan teman maupun keluarga (Ozen \& Engizek, 2014).

\section{Relaxation Shopping}

Dimensi dimana berbelanja dianggap sebagai suatu alternatif untuk mengatasi kepenatan, menghilangkan suasana hati negatif, dan sarana untuk melupakan permasalahan-permasalahan yang sedang dihadapi (Ozen \& Engizek, 2014).

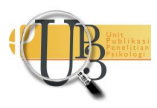


Berdasarkan penjelasan mengenai impulsive buying dan hedonic shopping motivations, penelitian ini menyusun hipotesis sebagai berikut:

H1: hedonic shopping motivations dimensi adventure shopping memiliki pengaruh terhadap variabel impulsive buying

H2: hedonic shopping motivations dimensi value shopping memiliki pengaruh terhadap variabel impulsive buying

H3: hedonic shopping motivations dimensi idea shopping memiliki pengaruh terhadap variabel impulsive buying

H4: hedonic shopping motivations dimensi social shopping memiliki pengaruh terhadap variabel impulsive buying

H5: hedonic shopping motivations dimensi relaxation shopping memiliki pengaruh terhadap variabel impulsive buying

\section{Desain Penelitian}

MET OD E

Penelitian ini menggunakan penelitian kuantitatif dengan teknik eksplanasi survei dengan menyebarkan kuesioner secara daring. Berdasarkan tingkat eksplanasinya, menurut Neuman (2007), penelitian ini termasuk dalam penelitian asosiatif dimana penulis ingin mengetahui hubungan antara dua variabel yang memiliki fungsi untuk meramalkan, menjelaskan, serta mengontrol satu variabel dengan variabel lainnya. Sedangkan dari dimensi waktu, penelitian ini termasuk dalam penelitian crosssectional karena hanya dilakukan dalam satu waktu (Neuman, 2007).

\section{Partisipan}

Partisipan dalam penelitian ini merupakan individu dengan rentang usia 19 - 25 tahun dan pernah melakukan pembelian produk fashion di website atau aplikasi Shopee Indonesia secara tidak terencana minimal satu kali dalam sebulan. Penelitian ini menggunakan metode non-probabilitas dengan teknik convenience sampling dimana sampel diambil dari kelompok orang yang mudah dijangkau (Neuman, 2007), dalam hal ini adalah pengguna e-commerce Shopee. Sebelum mengisi kuesioner, partisipan akan diminta untuk mengisi informed consent terlebih dahulu.

Jumlah partisipan dalam penelitian ini sebanyak 160 partisipan $\left(M_{\mathrm{usia}}=22,8\right.$; 82,5 persen perempuan; 17,5 persen laki-laki). Usia partisipan didominasi oleh usia 24 tahun $(48,1 \%)$, lalu partisipan dengan pekerjaan berupa mahasiswa lebih mendominasi $(45,6 \%)$.

\section{Pengukuran}

Pengukuran impulsive buying menggunakan Impulsive Buying Tendency (IBT) milik Verplanken dan Herabadi (2001) yang sudah diadaptasi dan diuji reliabilitasnya oleh Putri (2017). Skala ini terdiri dari 20 item yang mewakili 2 dimensi dalam impulsive buying, yaitu dimensi kognitif dan afektif. Skala ini disusun menggunakan skala likert dengan empat rentang respon 1 sampai 4 ("1"=sangat setuju hingga "4"=sangat tidak setuju).

Dalam mengukur hedonic shopping motivations menggunakan skala hedonic shopping motivations milik Ozen dan Engizek (2014) yang telah diadaptasi dan diuji reliabilitasnya oleh Mulianingsih (2018). Skala ini terdiri dari 16 item yang mewakili lima dimensi, yaitu adventure shopping, value shopping, idea shopping, social shopping, dan relaxation shopping. Skala ini disusun menggunakan skala likert dengan empat rentang respon 1 sampai 4 ("1"=sangat setuju hingga "4"=sangat tidak setuju). 
Validitas alat ukur impulsive buying pada penelitian ini telah diuji oleh Putri (2017) menggunakan teknik validitas isi dengan meminta bantuan professional judgement. Validitas alat ukur hedonic shopping motivations juga telah diuji oleh Mulianingsih (2018) menggunakan teknik validitas isi dengan meminta bantuan professional judgement.

Reliabilitas juga telah diuji menggunakan Cronbach's Alpha. Hasil uji reliabilitas yang didapatkan untuk kedua subskala impulsive buying tendency, yaitu kognitif dan afektif adalah .721 dan .868 secara terpisah. Sedangkan hasil uji reliabilitas yang didapatkan kelima subskala hedonic shopping motivations, yaitu adventure shopping, value shopping, idea shopping, social shopping, dan relaxation shopping adalah .822, .876, .926, .795, dan .925 secara terpisah.

\section{Analisis Data}

Uji asumsi yang telah dilakukan menunjukkan bahwa data penelitian terdistribusikan secara normal dan linear. Uji heteroskedastisitas melalui gambar scatter plots regression menunjukkan bahwa persebaran residu berada pada atas dan bawah angka 0 pada sumbu Y dan variasi residual memiliki variasi yang sama pada setiap tingkat pengamatan. Dengan begitu, data penelitian memenuhi semua asumsi dan uji regresi linear sederhana dapat dilakukan. Dalam mengolah data tersebut digunakan software IBM SPSS 25 for Windows.

\section{HAS IL P E N ELIT IAN}

Hasil analisis deskriptif menunjukkan bahwa partisipan yang memiliki impulsive buying paling tinggi terdapat pada kategori sedang sebanyak 60 partisipan $(37,5 \%)$ dan paling rendah terdapat pada kategori sangat rendah dengan 8 partisipan (5\%). Pada kategori hedonic shopping motivations dimensi adventure shopping dominan berada pada kategori sedang yaitu 62 partisipan (38,8\%). Dimensi value shopping dominan pada kategori sedang yaitu 86 partisipan (53,8\%). Dimensi idea shopping dominan pada kategori sedang sebanyak 72 partisipan (45\%). Dimensi social shopping dominan pada kategori sedang yaitu 80 partisipan (50\%). Terakhir, dimensi relaxation shopping dominan pada kategori sedang yaitu 59 partisipan $(36,9 \%)$.

Hasil analisis regresi linear sederhana antara adventure shopping dan impulsive buying menunjukkan bahwa adventure shopping dapat menjelaskan impulsive buying pada konsumen produk fashion sebesar $27,3 \%\left(F(1,158)=59.391 ; p<0,05 ; R^{2}=.273\right)$. Adventure shopping secara signifikan berpengaruh positif terhadap impulsive buying $(\beta=.990 ; p<0,05)$.

Hasil analisis regresi linear sederhana antara value shopping dan impulsive buying menunjukkan bahwa value shopping dapat menjelaskan impulsive buying pada konsumen produk fashion sebesar $11 \%$ ( $F$ $\left.(1,158)=19.519 ; p<0,05 ; R^{2}=110\right)$. Value shopping secara signifikan berpengaruh positif terhadap impulsive buying $(\beta=.705 ; p<0,05)$.

Hasil analisis regresi linear sederhana antara idea shopping dan impulsive buying menunjukkan bahwa idea shopping dapat menjelaskan impulsive buying pada konsumen produk fashion sebesar 25,1\% ( $F$ $\left.(1,158)=52.872 ; p<0,05 ; R^{2}=.251\right)$. idea shopping secara signifikan berpengaruh positif terhadap impulsive buying $(\beta=.758 ; p<0,05)$.

Hasil analisis regresi linear sederhana antara social shopping dan impulsive buying menunjukkan bahwa social shopping dapat menjelaskan impulsive buying pada konsumen produk fashion sebesar $14,2 \%(F$ 
$\left.(1,158)=26.213 ; p<0,05 ; R^{2}=.142\right)$. social shopping secara signifikan berpengaruh positif terhadap impulsive buying $(\beta=.790 ; p<0,05)$.

Terakhir, hasil analisis regresi linear sederhana antara relaxation shopping dan impulsive buying menunjukkan bahwa relaxation shopping dapat menjelaskan impulsive buying pada konsumen produk fashion sebesar $23,7 \%\left(F(1,158)=48.977 ; p<0,05 ; R^{2}=.237\right)$. Relaxation shopping secara signifikan berpengaruh positif terhadap impulsive buying $(\beta=.798 ; p<0,05)$.

\section{I S K U S I}

Tujuan dari penelitian ini adalah untuk melihat pengaruh hedonic shopping motivations terhadap impulsive buying pada konsumen produk fashion. Dari analisi yang telah dilakukan, ditemukan hasil yang menunjukkan nilai $\mathrm{R}^{2}$ sebesar 0,273 yang diartikan nilai adventure shopping memiliki pengaruh terhadap impulsive buying sebesar 27,3\%. Hasil tersebut sejalan dengan hasil penelitian yang dilakukan oleh Ozen dan Engizek (2014) yang menunjukkan bahwa terdapat pengaruh positif dan signifikan antara adventure shopping terhadap impulsive buying. adventure shopping yang berpengaruh terhadap impulsive buying ini bisa disebabkan karena mayoritas konsumen berusia 19-25 tahu dimana usia ini sangat dekat dengan perkembangan teknologi dan internet sehingga dapat dengan mudah menemukan variasi produk atau jasa terbaru pada proses berbelanja yang menuntun pada impulsive buying (Ozen \& Engizek, 2014).

Nilai $\mathrm{R}^{2}$ value shopping sebesar 0,110 yang diartikan nilai value shopping memiliki pengaruh terhadap impulsive buying sebesar 11\%. Hasil tersebut sejalan dengan hasil penelitian yang dilakukan oleh Ozen dan Engizek (2014) yang menunjukkan bahwa terdapat pengaruh positif dan signifikan antara value shopping terhadap impulsive buying. Konsumen dapat dengan mudah mencari dan mengumpulkan kupon diskon maupun penawaran produk sehingga membuat konsumen terdorong untuk melakukan pembelanjaan yang tidak direncanakan. Diskon, produk sale, dan penawaran produk berkaitan dengan harga. Menurut teori, harga dianggap sebagai faktor utama yang mendorong konsumen untuk melakukan pembelian secara impulsif (Ozen \& Engizek, 2014).

Nilai $\mathrm{R}^{2}$ idea shopping sebesar 0,251 yang diartikan nilai idea shopping memiliki pengaruh terhadap impulsive buying sebesar $25,1 \%$. hal ini bisa dikarenakan e-commerce menyediakan informasi mengenai produk, merek, dan tren terbaru yang membuat konsumen lebih memilih untuk berbelanja melalui $e$ commerce. Selain itu, juga mempermudah penggunanya untuk mencari informasi melalui key words, iklan, sponsorship, ulasan produk, dan membandingkan harga. Dengan banyaknya informasi yang tersedia secara online, maka semakin banyak pula konsumen yang mengakses laman Shopee dan mendorong konsumen melakukan pembelian impulsif (Ozen \& Engizek, 2014).

Nilai $\mathrm{R}^{2}$ social shopping sebesar 0,142 yang diartikan nilai social shopping memiliki pengaruh terhadap impulsive buying sebesar 14,2\%. Hal ini bisa dikarenakan e-commerce memiliki fasilitas pemberian ulasan pada produk, pemberian penilaian berupa rating, dan fitur berbagi link atau menuliskan blog mengenai pengalaman berbelanja yang memudahkan konsumen satu dan lainnya berdiskusi mengenai suatu produk. Selain itu, diketahui bahwa salah satu alasan konsumen memilih berbelanja online karena ingin menghindari interaksi dengan salesperson. Seiring berkembangnya teknologi, social shopping memberikan pengalaman berbelanja yang lebih menarik serta menawarkan kebebesan yang mendorong konsumen untuk melakukan pembelian impulsif (Ozen \& Engizek, 2014). 
Nilai $\mathrm{R}^{2}$ sebesar 0,237 yang diartikan nilai relaxation shopping memiliki pengaruh terhadap impulsive buying sebesar 23,7\%. Hal ini bisa dikarenakan relaxation shopping merupakan dimensi yang melibatkan berbelanja untuk melepas rasa penat dan mengubah negative mood menjadi positive mood. Beberapa konsumen mengakui bahwa mereka berbelanja untuk mengurangi stres, melupakan masalah, cara untuk menenangkan diri, atau hanya sekedar ingin melarikan diri dari realita. Dengan begitu, secara logika relaxation shopping mendorong konsumen untuk melakukan pembelian impulsif (Ozen \& Engizek, 2014).

\section{S I M P U L A N}

Berdasarkan hasil penelitian yang sudah dilakukan, kesimpulan akhirnya ialah sebagai berikut, hipotesis aletrnatif $\left(\mathrm{H}_{\mathrm{a}}\right)$ diterima dan hipotesis null $\left(\mathrm{H}_{0}\right)$ ditolak. Hal ini menunjukkan bahwa hasil yang diperoleh dari penelitian ini adalah terdapat pengaruh yang signifikan antara Hedonic Shopping Motivations terhadap Impulsive Buying pada Konsumen Produk Fashion.

Saran untuk penelitian berikutnya diharapkan dapat menjadikan penelitian ini sebagai bahan pertimbangan dengan mengambil variabel lain yang dapat mempengaruhi Impulsive Buying. Lalu penelitian selanjutnya sebaiknya memberikan batasan yang jelas untuk jumlah minimal suatu pembelian yang dikatakan sebagai impulsive buying. Kemudian penelitian selanjutnya disarankan untuk menentukan beberapa kriteria produk yang dibeli sehingga peneliti dapat mengetahui barang jenis apa yang cenderung dibeli secara impulsif oleh konsumen.

Selain itu juga penelitian selanjutnya disarankan menggali data subjek lebih banyak dengan menambahkan faktor ekonomi dan data demografis lainnya. Perusahaan dapat menstimulasi konsumen untuk membeli lebih dengan memberikan "related product" pada laman produk yang ingin dibeli, contohnya pada saat konsumen membeli baju, perusahaan dapat memberi sugesti celana. Kombinasi ini dapat mendorong konsumen untuk melakukan pembelian lebih. Menstimulasi dengan memberikan diskon pengiriman dengan minimal jumlah belanjaan tertentu. Menggunakan sosial media untuk meningkatkan intensitas kunjungan pada e-commerce melalui iklan-iklan.

\section{U C A P A N T ERIMAKASIH}

Terima kasih penulis ucapkan kepada Tuhan Yang Maha Esa, keluarga, rekan-rekan, serta pihak lain yang mendukung dan berkontribusi dalam proses penelitian.

\section{DEKLARASI POTENSI TERJADINYAKONFLIKKEPENTINGAN}

Diyah Ranasari dan Fajrianthi tidak bekerja, menjadi konsultan, memiliki saham, atau menerima dana dari perusahaan atau organisasi maupun yang mungkin akan mengambil untung dari diterbitkannya naskah ini. 


\section{PUSTAKA ACUAN}

Apriyani, $\quad$ T. $\quad$ (2020, Februari 10). Diambil kembali dari https://yoursay.suara.com/news/2020/02/10/162614/pengaruh-e-commmerce-terhadappertumbuhan-ekonomiindonesia?page=all

Arnold, M. J., \& Reynolds, K. E. (2012). Approach and Avoidance Motivation: Investigating Hedonic Consumption in Retail Setting. Journal of Retailing, 399-411.

Bagas, A. (2020, June 30). Diambil kembali dari https://shopee.co.id/inspirasi-shopee/kelebihanbelanja-di-shopee-dari-gratis-ongkir-hingga-ada-layanan-ekspedisi-sendiri/

Kemp, S. (2020, Februari 18). Diambil kembali dari https://datareportal.com/reports/digital-2020indonesia

Kemp, S., \& Moey, S. (2019, September 18). Diambil kembali dari https://datareportal.com/reports/digital-2019-ecommerce-in-indonesia

Khan, A. G. (2016). Electronic Commerce: A Study on Benefits and Challenges in an Emerging Economy. Global Journal of Management And Business Research, 1-5.

Khurana, A. (2019, November 20). Diambil kembali dari https://www.thebalancesmb.com/advantagesof-ecommerce-1141610

Kurniawan, G. $\quad(2014, \quad$ Maret 21). Diambil kembali dari https://teknologi.bisnis.com/read/20140321/105/212771/ternyata-tingkat-kepuasanbelanja-online-indonesia-tertinggi

Mahatma, R. (2016, Desember 13). Diambil kembali dari BuatTokoOnline: https://buattokoonline.id/data-konsumen-dan-potensi-perkembangan-ecommerce-indonesia2016/

Marketeers. (2012, April 25). Diambil kembali dari https://marketeers.com/segmentasi-anak-mudaindonesia-berdasarkan-spending-behavior/

Neuman, W. L. (2007). Metode Penelitian Sosial: Pendekatan Kualitatif dan Kuantitatif. Jakarta: PT Indeks.

Ozen, H., \& Engizek, N. (2014). Shopping Online Without Thinking: being emotional or rational? Asia Pacific Journal of Marketing and Logistic, 78-93.

Rook, D. W. (1987). The Buying Impulse. Journal of Consumer Research, 189-199.

Tempo. (2011, Juni 21). Diambil kembali dari https://m.tempo.co/read/news/2011/06/21/090342265/pembelanjaindonesia-makinimpulsif 
Utami, A. F., \& Sumaryono. (2008). Pembelian Impulsif Ditinjau dari Kontrol Diri dan Jenis Kelamin pada Remaja. Jurnal Psikologi Proyeksi, 46-57.

Verhagen, T., \& Dolen, V. W. (2011). The Influence of Online Store Beliefs on Consumers Online Impulse Buying: A Model and Empirical Application. Journal of Information and Management, 320-327.

Verplanken, B., \& Herabadi, A. G. (2001). Individual Differences in Impulse Buying Tendency: Feeling and No Thinking. European Journal of Personality, S71-S83.

Yaqoub, A. M. (2020, Desember 12). Diambil kembali dari https://www.jawapos.com/opini/12/12/2020/sisi-gelap-harbolnas-dan-cara-memperbaikinya/ 